\title{
Enhanced photocytotoxicity of curcumin delivered by solid lipid nanoparticles
}

\author{
This article was published in the following Dove Press journal: \\ International Journal of Nanomedicine \\ 22 December 2016 \\ Number of times this article has been viewed
}

\author{
Shan Jiang' \\ Rongrong Zhu' \\ Xiaolie $\mathrm{He}^{1}$ \\ Jiao Wang' \\ Mei Wang' \\ Yechang Qian ${ }^{2}$ \\ Shilong Wang'
}

'Tenth People's Hospital, School of Life Science and Technology, Tongii University, ${ }^{2}$ Department of Respiratory Disease, Baoshan District Hospital of Integrated Traditional Chinese and Western Medicine, Shanghai, People's Republic of China

Correspondence: Yechang Qian Department of Respiratory Disease, Baoshan District Hospital of Integrated Traditional Chinese and Western Medicine, I8I Youyi Road, Shanghai 201900, People's Republic of China

Tel +8621 659l 8108

Fax +86 2I 36070892

Email qianyechang@163.com

Shilong Wang

Tenth People's Hospital, School of Life Science and Technology, Tongji University, I 239 Siping Road, Shanghai 200092, People's Republic of China

Tel +86 2l 65982595

Fax +86 21 65982595

Email wsl@tongji.edu.cn

\begin{abstract}
Curcumin (Cur) is a promising photosensitizer that could be used in photodynamic therapy. However, its poor solubility and hydrolytic instability limit its clinical use. The aim of the present study was to encapsulate Cur into solid lipid nanoparticles (SLNs) in order to improve its therapeutic activity. The Cur-loaded SLNs (Cur-SLNs) were prepared using an emulsification and low-temperature solidification method. The functions of Cur and Cur-SLNs were studied on the non-small cell lung cancer A549 cells for photodynamic therapy. The results revealed that Cur-SLNs induced 2.27-fold toxicity higher than free Cur at a low concentration of $15 \mu \mathrm{M}$ under light excitation, stocking more cell cycle at G2/M phase. Cur-SLNs could act as an efficient drug delivery system to increase the intracellular concentration of Cur and its accumulation in mitochondria; meanwhile, the hydrolytic stability of free Cur could be improved. Furthermore, Cur-SLNs exposed to $430 \mathrm{~nm}$ light could produce more reactive oxygen species to induce the disruption of mitochondrial membrane potential. Western blot analysis revealed that Cur-SLNs increased the expression of caspase-3, caspase- 9 proteins and promoted the ratio of Bax/Bcl-2. Overall, the results from these studies demonstrated that the SLNs could enhance the phototoxic effects of Cur.
\end{abstract}

Keywords: photodynamic therapy, curcumin, solid lipid nanoparticles, drug delivery, reactive oxygen species

\section{Introduction}

Photodynamic therapy (PDT) is a minimally invasive technique that shows negligible drug resistance, remarkable selectivity, high controllability, and low systemic toxicity when compared with traditional chemotherapies and radiotherapies. ${ }^{1-3}$ PDT involves three key components: light exposure, photosensitizer, and oxygen. When a photosensitizer is exposed to light of an appropriate wavelength, the excited photosensitizer transfers energy to oxygen, generates reactive oxygen species (ROS), and damages cancer cells. ${ }^{4,5}$ Undoubtedly, the discovery and optimization of photosensitizer are essential to the development of PDT.

Curcumin (Cur), a polyphenol extracted from the turmeric root, has been shown to exhibit antimicrobial, anti-inflammatory, and anticancer activities. ${ }^{6-8}$ The photocytotoxic effects of Cur have been recently discovered. ${ }^{9-19}$ However, the extremely low aqueous solubility and hydrolytic instability under physiological conditions limit its uses. ${ }^{20-22}$ Many nanoparticles have been used to improve its stability, aqueous solubility, and bioavailability, such as layered double hydroxides, poly(lactide-co-glycolide), chitosan, cellulose, nanogel, and cyclodextrin. ${ }^{8,23-26}$

Solid lipid nanoparticles (SLNs) synthesized with different types of physiological lipids have attracted increasing attention as a novel drug carrier because of their 
potential advantages, including good biocompatibility, protection for the incorporated compound against degradation, and less toxicity. ${ }^{27-31}$

In this study, we aimed to improve the photocytotoxicity of Cur by SLNs for cancer treatment. Cur-SLNs were successfully synthesized using emulsification and lowtemperature solidification methods and characterized by transmission electron microscopy (TEM) analyses, zeta potential detection, and photon correlation spectroscopy. The results showed that in A549 cells, in comparison with Cur, Cur-SLNs could largely induce tumor cell apoptosis and further arrest cell cycle. Confocal microscopy imaging clearly visualized that the delivery of Cur-SLNs to A549 cells was better than that of free Cur. In order to explore the molecular mechanism by which the SLNs can improve the PDT effects of Cur, we investigated the protein expression of Bcl-2, Bax, caspase-3, and caspase-9 through Western blot analysis. Altogether, our data showed the promise of potential applications of delivering Cur as SLNs for PDT.

\section{Materials and methods Materials}

Polyoxyethylene(40)stearate (Myrj52), stearic acid, chloroform, lecithin, Tween-80, 3-(4,5-dimethylthiazol-2-yl)-2,5-diphenyltetrazolium bromide (MTT), and 2-(4-amidinophenyl)-6indolecarbamidine dihydrochloride were obtained from Sinopharm Chemical Reagent Co. Ltd. (Shanghai, People's Republic of China). Cur ( $\geq 98 \%$ ) was purchased from Aladdin Chemistry Co. Ltd. (Shanghai, People's Republic of China). $\beta$-Actin, caspase-3, caspase-9, Bax, and Bcl-2 antibodies were purchased from Cell Signaling Technology Inc. Nucleoprotein and cytoplasmic protein extraction kit, bicinchoninic acid protein assay reagent, Annexin V-APC/7-amino-actinomycin D (7-AAD) apoptosis detection kit, cell cycle detection kit, 3'-tetraethylbenzimidazolcarbocyanine iodide (JC-1) apoptosis detection kit, and ROS detection kit were purchased from KeyGEN Biotech (Nanjin, People's Republic of China). Dimethyl sulfoxide was purchased from Sigma Chemical Co. (St Louis, MO, USA), and MitoTracker-Red was from Invitrogen (Carlsbad, CA, USA). Water was prepared using a Millipore Milli- ${ }^{\circledR}$ system (Bedford, MA, USA) and decarbonated by boiling. Roswell Park Memorial Institute (RPMI)-1640, penicillin-streptomycin, fetal calf serum, and trypsinase were purchased from Gibco (BRL, Grand Island, NY, USA).

\section{Preparation of Cur-SLNs}

Cur-SLNs were prepared using emulsification and lowtemperature solidification methods. ${ }^{8,28,29}$ The organic phase containing $0.1 \mathrm{~g}$ lecithin, $0.15 \mathrm{~g}$ Cur, and $0.2 \mathrm{~g}$ stearic acid was dissolved in $10 \mathrm{~mL}$ of chloroform. Also, $0.2 \mathrm{~g}$ of Myrj52 dissolved in $30 \mathrm{~mL}$ of deionized water formed the aqueous phase. After complete dissolution of the aqueous phase at $75^{\circ} \mathrm{C}$, the organic phase was injected into it and stirred at 1,200 rpm until the organic solvent disappeared. Then the system was quickly moved to an ice-cold environment at $0^{\circ} \mathrm{C}-2^{\circ} \mathrm{C}$, added to $10 \mathrm{~mL}$ of cold water, and stirred at $1,200 \mathrm{rpm}$ for $2 \mathrm{~h}$. Centrifugal separation was applied to remove the supernatant at 20,000 rpm (Avanti J25 centrifuge, JA 25.50 rotor, Beckman Coulter). The precipitate was washed by deionized water twice. Finally, the precipitate was resuspended in ultrapure water, refrigerated at $-80^{\circ} \mathrm{C}$ overnight, and lyophilized in a tabletop lyophilizer. The blank carriers (SLNs) were prepared using the same procedure without the addition of Cur.

\section{TEM, particle size, and zeta potential measurements}

A drop of a diluted suspension of Cur-SLNs was placed on a carbon-coated copper TEM grid to form a thin liquid film, negatively stained with $2 \%(\mathrm{w} / \mathrm{v})$ sodium phosphotungstate for $10 \mathrm{~min}$ and allowed to air-dry, and examined with a transmission electron microscope (JEOL, Tokyo, Japan). The particle size and the zeta potential of Cur-SLNs were measured using a Malvern Zeta-sizer Nano ZS (Malvern Instruments, Malvern, UK). The experiments were repeated three times.

\section{Quantifying the loading efficiency of Cur}

The amount of loaded Cur in Cur-SLNs was determined by ultraviolet-visible spectroscopy at $430 \mathrm{~nm}$. Cur-SLNs were diluted with ethanol to the range covered within the standard curve. The concentration of Cur was calculated according to a previously obtained calibration curve for Cur (Absorption $=0.1517 \mathrm{c}+0.022, r^{2}=0.999$ ). The experiments were repeated three times. The drug loading capacity was calculated as follows:

$$
\begin{gathered}
\text { Drug loading } \\
\text { capacity }
\end{gathered}=\frac{\text { Weight of Cur in Cur-SLNs }}{\text { Weight of Cur-SLNs }} \times 100 \% \text {. }
$$

\section{Cell culture and cellular uptake studies}

A549 cells obtained from Type Culture Collection of the Chinese Academy of Sciences, Shanghai, China, were cultured at $37^{\circ} \mathrm{C}$ in a humidified $5 \% \mathrm{CO}_{2}$ Thermo cell incubator, with RPMI-1640 medium supplemented with 10\% fetal calf serum, penicillin $(100 \mathrm{U} / \mathrm{mL})$, and streptomycin $(100 \mu \mathrm{g} / \mathrm{mL})$.

A549 cells were seeded in glass-bottom dishes and then treated with $15 \mu \mathrm{M}$ free Cur or Cur-SLNs. After 1, 2, and 
$4 \mathrm{~h}$ of incubation, the cells were washed three times with phosphate-buffered saline (PBS; $\mathrm{pH} 7.4$ ) to remove excess free Cur or Cur-SLNs. Fresh RPMI-1640 medium was added to the dishes and the cells were observed under confocal laser scanning microscope (Leica TCS SP5; Leica Microsystems $\mathrm{GmbH}$, Wetzlar, Germany). The experiments were repeated three times.

\section{Detection of ROS}

A549 cells were plated in 12 -well plates at $37^{\circ} \mathrm{C}$ for $16-24 \mathrm{~h}$. After incubation with free Cur and Cur-SLNs (15 $\mu \mathrm{M}$ of free Cur equivalent) for $4 \mathrm{~h}$, the cells were washed with PBS buffer to remove excess Cur and Cur-SLNs outside the cells. Each well was exposed to a $430 \mathrm{~nm}$ light-emitting diode (LED; power density $50 \mathrm{~mW} / \mathrm{cm}^{2}$ ) for $20 \mathrm{~min}$ at the same distance to supply the same power. After incubation for $12 \mathrm{~h}$, the cells were washed and harvested. Then, $150 \mu \mathrm{L}$ of $10 \mu \mathrm{M} 2^{\prime}, 7^{\prime}$-dichlorofluorescin diacetate was added to the cell suspension and incubated for $20 \mathrm{~min}$ at room temperature in the dark. Exactly 20,000 cells were analyzed using flow cytometry analysis with analytical flow cytometry instrument (BD FACSVerse). ${ }^{32,33}$ The experiments were repeated three times.

\section{Cytotoxicity assay}

MTT assay was used to assess the metabolic activity of A549 cancer cells. ${ }^{32}$ Briefly, A549 cells were seeded into 96-well plates. After 16-24 h of incubation, the cells were treated with various concentrations of free Cur, Cur-SLNs, and SLNs for $4 \mathrm{~h}$. Then, the cells were washed with fresh media twice and exposed to $430 \mathrm{~nm}$ LED for $20 \mathrm{~min}$. After incubation for $12 \mathrm{~h}$ in the dark, the cells were incubated with $20 \mu \mathrm{L}$ MTT $(5 \mathrm{mg} / \mathrm{mL})$ for $4 \mathrm{~h}$ at $37^{\circ} \mathrm{C}$, followed by treatment with $150 \mu \mathrm{L}$ dimethyl sulfoxide to dissolve the crystals. The absorbance was quantified at $492 \mathrm{~nm}$ using Elx 800 Universal Microplate Reader (BIO-TEK, Inc.). The errors were calculated from three independent set of experiments, each of which was performed in triplicate.

\section{Trypan blue assay}

A549 cells were seeded in $35 \mathrm{~mm}$ culture dishes and treated with $15 \mu \mathrm{M}$ Cur-SLNs or free Cur. After incubation for $4 \mathrm{~h}$, the cells were washed with PBS twice and exposed to $430 \mathrm{~nm}$ LED for $20 \mathrm{~min}$. Following incubation in the dark for $12 \mathrm{~h}$, the cells were stained with $0.04 \%$ Trypan blue solution for $5 \mathrm{~min}$. Then, the A549 cells were observed using a Leica microscope. ${ }^{34}$ The experiments were repeated three times.

\section{Mitochondrial membrane potential assay}

A549 cells were seeded into six-well plates and treated with $15 \mu \mathrm{M}$ Cur-SLNs or free Cur for $4 \mathrm{~h}$. Then, the cells were washed with PBS buffer and exposed to $430 \mathrm{~nm}$ LED for $20 \mathrm{~min}$. After incubation in the dark for $12 \mathrm{~h}$, the cells were harvested and stained with $2 \mu \mathrm{M} \mathrm{JC}-1$ dye in $500 \mu \mathrm{L}$ PBS for $30 \mathrm{~min}$. The fluorescence intensity of each sample was detected by FACSCalibur. The experiments were repeated three times.

\section{Apoptosis analysis}

A549 cells were seeded in six-well plates for 16-24 h and incubated with $15 \mu \mathrm{M}$ free Cur and Cur-SLNs for $4 \mathrm{~h}$. They were then washed with PBS buffer twice and exposed to $430 \mathrm{~nm}$ LED for $20 \mathrm{~min}$. After incubation for $12 \mathrm{~h}$, the cells were collected and fixed in $500 \mu \mathrm{L}$ of Annexin V binding buffer containing $5 \mu \mathrm{L}$ Annexin V-APC and $5 \mu \mathrm{L}$ 7-AAD. After incubation at room temperature for $20 \mathrm{~min}$ in the dark, 20,000 cells were analyzed using fluorescence-activated cell sorter analysis. The experiments were repeated three times.

\section{Cell cycle}

A549 cells were seeded in six-well plates for 16-24 h and treated with Cur and Cur-SLNs $(15 \mu \mathrm{M}$ of free Cur equivalent) for $4 \mathrm{~h}$. They were then exposed to $430 \mathrm{~nm}$ LED for $20 \mathrm{~min}$. After $12 \mathrm{~h}$, the trypsinized cells were suspended in chilled $70 \%$ ethanol which contained $50 \mu \mathrm{g} / \mathrm{mL}$ propidium iodide and $100 \mu \mathrm{g} / \mathrm{mL}$ RNase A. After staining for $30 \mathrm{~min}$, 20,000 cells were analyzed by flow cytometry. The experiments were repeated three times.

\section{Western blot analysis}

A549 cells were treated with Cur and Cur-SLNs $(15 \mu \mathrm{M}$ of free Cur equivalent) and exposed to $430 \mathrm{~nm}$ LED for $20 \mathrm{~min}$, and then incubated for $12 \mathrm{~h}$ in the dark. The cells were collected for protein extraction. Twenty microgram protein samples were denatured by sodium dodecyl sulfatepolyacrylamide gelelectrophoresis, then separated by gel electrophoresis, and transferred to polyvinylidene difluoride membrane. After blocking by 5\% bovine serum albumin, the primary antibodies $\beta$-actin, Bax, Bcl-2, and caspase-3, caspase-9 (1:1,000 dilution), and a secondary antibody were used to probe the protein levels. The signal was visualized with a chemiluminescent electrochemiluminescent detection system. The experiments were repeated three times.

\section{Statistical analysis}

Statistical analysis was performed using Student's $t$-test. All values were expressed as mean \pm standard deviation (SD). $P<0.05$ was considered as statistically significant. 


\section{Results}

Preparation and characterization of CurSLNs

Cur-loaded SLNs were prepared using emulsification and low-temperature solidification methods following our previously reported procedures. ${ }^{8,28,29}$ TEM images (Figure 1A) revealed a discrete spherical outline, which was in accordance with photon correlation spectroscopy. The zeta potential (Figure 1B) of the SLNs was $-26.2 \pm 1.3 \mathrm{mV}$, which is sufficiently high to cause the Cur-SLNs to repel each other, thereby avoiding particle aggregation and encouraging long-term stability. ${ }^{35}$ As shown in Figure $1 \mathrm{C}$, the average diameter of the Cur-SLNs particles was $56.2 \mathrm{~nm}$. To confirm the encapsulation and formulation of the Cur loaded in SLNs, the photophysical properties of Cur were examined. Free Cur has a distinctly high absorbance peak at $430 \mathrm{~nm}$ when dissolved in an ethanolic solution. The drug loading capacity was calculated as $37 \% \pm 2.5 \%$.

\section{Cell viability assay}

As shown in Figure 2, without light exposure, Cur-SLNs and free Cur exhibited negligible cytotoxicity to A549 cells. After having been exposed, on treatment with $10 \mu \mathrm{M}$ free Cur and Cur-SLNs, the viability of A549 cells was found to be $67 \%$ and $27 \%$, respectively. When A549 cells treated with $15 \mu \mathrm{M}$ free Cur and Cur-SLNs, the viability was $40 \%$ and $18 \%$, respectively. As expected, SLNs displayed no cytotoxicity to A549 cells either in the dark or under light exposure. Microscopic images of trypan blue stained cells further confirmed the improved PDT efficiency of Cur-SLNs over free Cur.

\section{Apoptosis analysis by Annexin V-APC and 7-AAD staining}

Annexin V-APC/7-AAD staining, a more sensitive method for detecting apoptosis, ${ }^{36}$ was used to determine whether Cur-SLNs demonstrated superior anticancer effects compared to free Cur. After the A549 cells were exposed to $430 \mathrm{~nm}$ LED for $20 \mathrm{~min}$, as shown in Figure 3, 27.33\% of apoptotic cells (early apoptosis plus late apoptosis) were found in the sample incubated with Cur only. When treated with Cur-SLNs (15 $\mu \mathrm{M}), 69.58 \%$ of apoptotic A549 cells were induced to apoptosis. In conclusion, Cur-SLNs displayed a stronger anticancer effect in A549 cells, compared to free Cur.

\section{Cell cycle studies}

The DNA content of cells was measured with propidium iodide. ${ }^{37}$ As shown in Figure 4, treating A549 cells with Cur and Cur-SLNs in the dark did not alter the cell cycle, compared
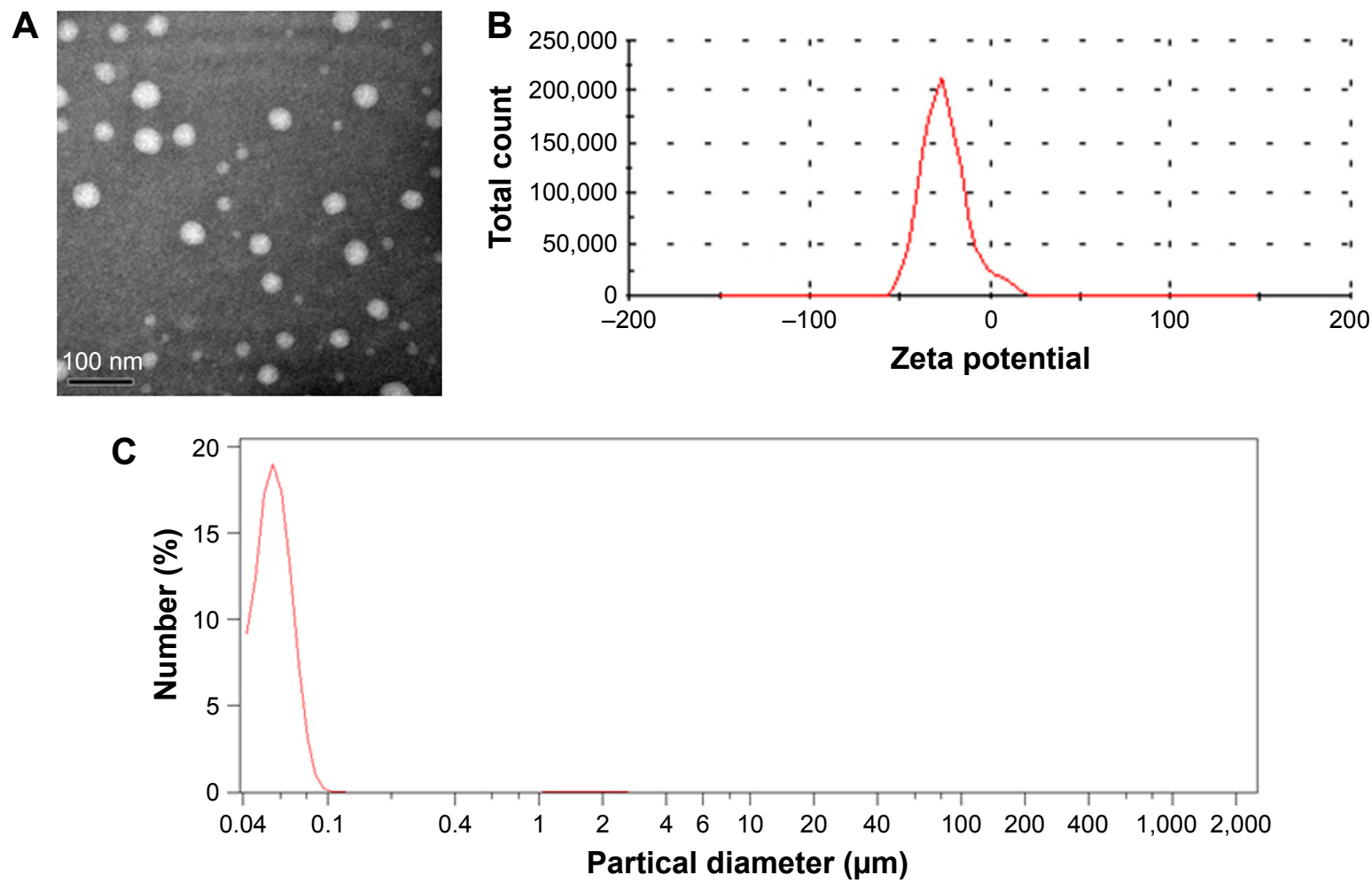

Figure I Characterization of Cur-SLNs.

Notes: Transmission electron microscopy image (A), zeta potential distribution (B), and particle size distribution (C) of Cur-SLNs.

Abbreviation: Cur-SLNs, curcumin-loaded solid lipid nanoparticles. 

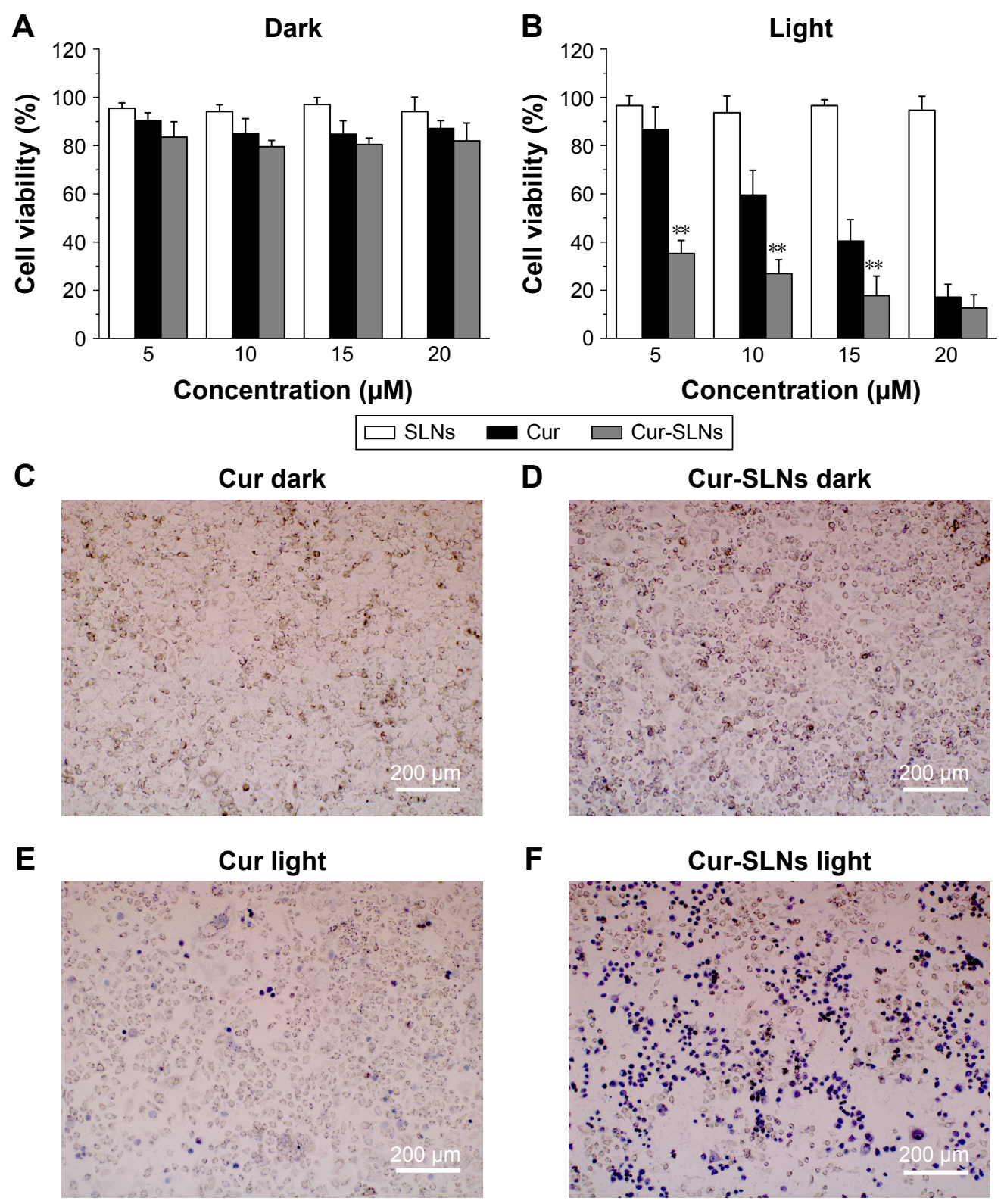

Figure 2 Killing of in vitro photodynamic cancer cells.

Notes: Cell viabilities of the A549 cells treated with Cur, SLNs, Cur-SLNs in the dark (A), and with light irradiation (B). Trypan blue stained images of A549 cells (C-F) incubated with Cur or Cur-SLNs with and without laser irradiation. The statistical significances in Cur and Cur-SLNs groups were determined using a two-sample Student's $t$-test. The data are shown as mean \pm standard deviation of three experiments, $* * P<0.01$.

Abbreviations: Cur, curcumin; Cur-SLNs, curcumin-loaded solid lipid nanoparticles.

with the untreated control group. In contrast, after they were exposed to the excitation light at $430 \mathrm{~nm}$, A549 cells treated with Cur-SLNs showed $49.26 \%$ arrest in G2/M phase of cell cycle leading to cell death and the cells treated with Cur showed $25.29 \%$ arrest in G2/M phase. These data suggest that CurSLNs showed more significant cell cycle arrest at G2/M phase in A549 cells at the same concentration after exposure.

\section{Cellular uptake and localization}

A549 cells were incubated with Cur-SLNs or free Cur at the same concentration $(15 \mu \mathrm{M})$ for 1,2 , and $4 \mathrm{~h}$ at $37^{\circ} \mathrm{C}$ and then imaged under a confocal fluorescence microscope. As shown in Figure 5, free Cur showed a little green fluorescence at $1 \mathrm{~h}$, whereas at $4 \mathrm{~h}$, its fluorescence intensity disappeared, possibly due to degradation from the time-dependent absorption spectra, which was also confirmed by other studies as mentioned earlier. However, cells treated with Cur-SLNs showed gradually increasing fluorescence intensity over time; when observed at $4 \mathrm{~h}$ of incubation, the cellular uptake of Cur-SLNs was much higher than that of free Cur. It has been reported that SLNs could enhance drug bioavailability by increasing Cur delivery and residence time through adhesion to the cellular 

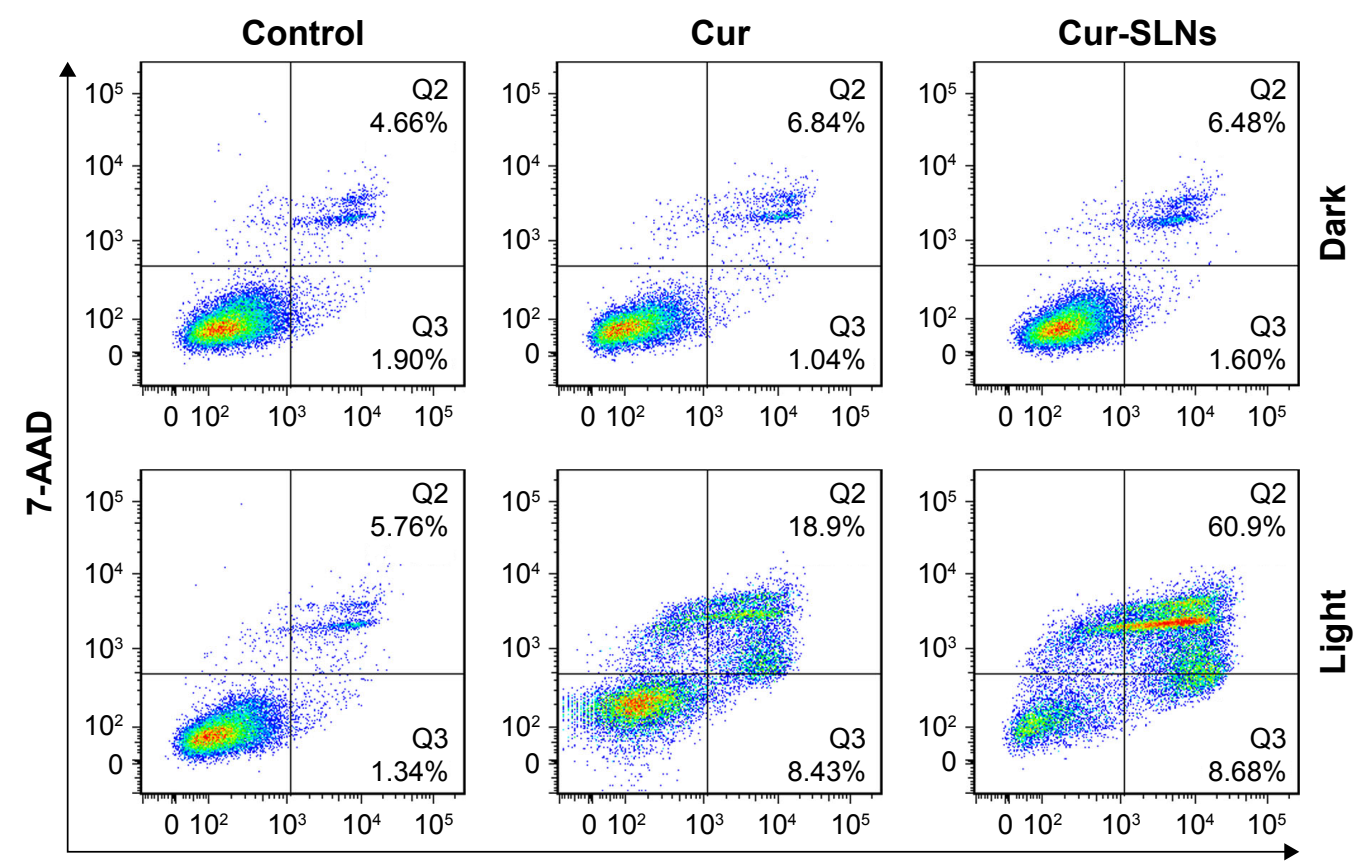

Annexin V-APC

Figure 3 FACS profiles of Annexin V-APC/7-AAD staining of A549 cells undergoing apoptosis induced by Cur and Cur-SLNs in the dark or with irradiation. Abbreviations: Cur, curcumin; Cur-SLNs, curcumin-loaded solid lipid nanoparticles; FACS, fluorescence-activated cell sorter.

surface..$^{38,39}$ The 2-(4-amidinophenyl)-6-indolecarbamidine dihydrochloride staining data revealed that the nuclear morphology remained unchanged in the dark, indicating the noncytotoxic nature of Cur-SLNs or free Cur in the dark.

In order to evaluate the capability of Cur to selectively target mitochondria, colocalization imaging experiments were performed in A549 cells. Mito-Tracker Green, a commercial mitochondrial dye, was employed to label mitochondria. As shown in Figure 6, the fluorescence of Cur overlapped well with that of Mito-Tracker Green. This could suggest that CurSLNs and free Cur were specifically bound to intracellular mitochondria. Also, accumulation of Cur-SLNs-treated cells was even much stronger than free Cur in the mitochondria.

\section{ROS generation of Cur-SLNs}

As shown in Figure 7, no obvious change in ROS was detected in the dark group. When A549 cells were directly exposed to $430 \mathrm{~nm}$, the Cur-SLNs were irradiated to produce more ROS (55.0\%) than the free Cur (23.2\%). This assay indicated that photoactivation of Cur-SLNs increased intracellular ROS levels, resulting in a better PDT effect in killing cancer cells.

\section{Cur-SLNs induced mitochondrial dysfunction}

In order to investigate whether Cur-SLN-induced apoptosis in A549 cells involves alterations in mitochondrial membrane potential, we used a JC-1 probe to monitor the changes in mitochondrial membrane potential of Cur-SLNs-treated cells by flow cytometry. As shown in Figure 8, the JC-1 monomer/ aggregate ratio was 0.55 in Cur-treated group, while it was 1.28 in the Cur-SLNs-treated group. The data suggest that treating A549 cells with Cur-SLNs resulted in disruption of mitochondrial membrane potential. Also, mitochondrial dysfunction might be involved in the process of Cur-SLNinduced apoptosis.

\section{Western blot analysis}

Figure 9 reveals that after PDT treatment, the expression levels of Bax, caspase-3, and caspase-9 were upregulated and the expression of antiapoptotic Bcl-2 was downregulated, compared to dark treatment. After exposure, the expression levels of Bax, caspase- 3 , and caspase- 9 induced by Cur-SLNs were much higher than those of free Cur-treated group; also, the expression of $\mathrm{Bcl}-2$ was lower compared to that with Cur treatment. This result shows that SLNs could enhance the PDT effects of Cur.

\section{Discussion}

In a previous study, we encapsulated Cur into SLNs to improve its dispersity and stability for enhancing the antiinflammatory activity of Cur. ${ }^{8}$ In this study, we demonstrated that SLNs could act as an effective carrier to deliver Cur and exhibit a higher photodynamic toxicity to A549 cells. 

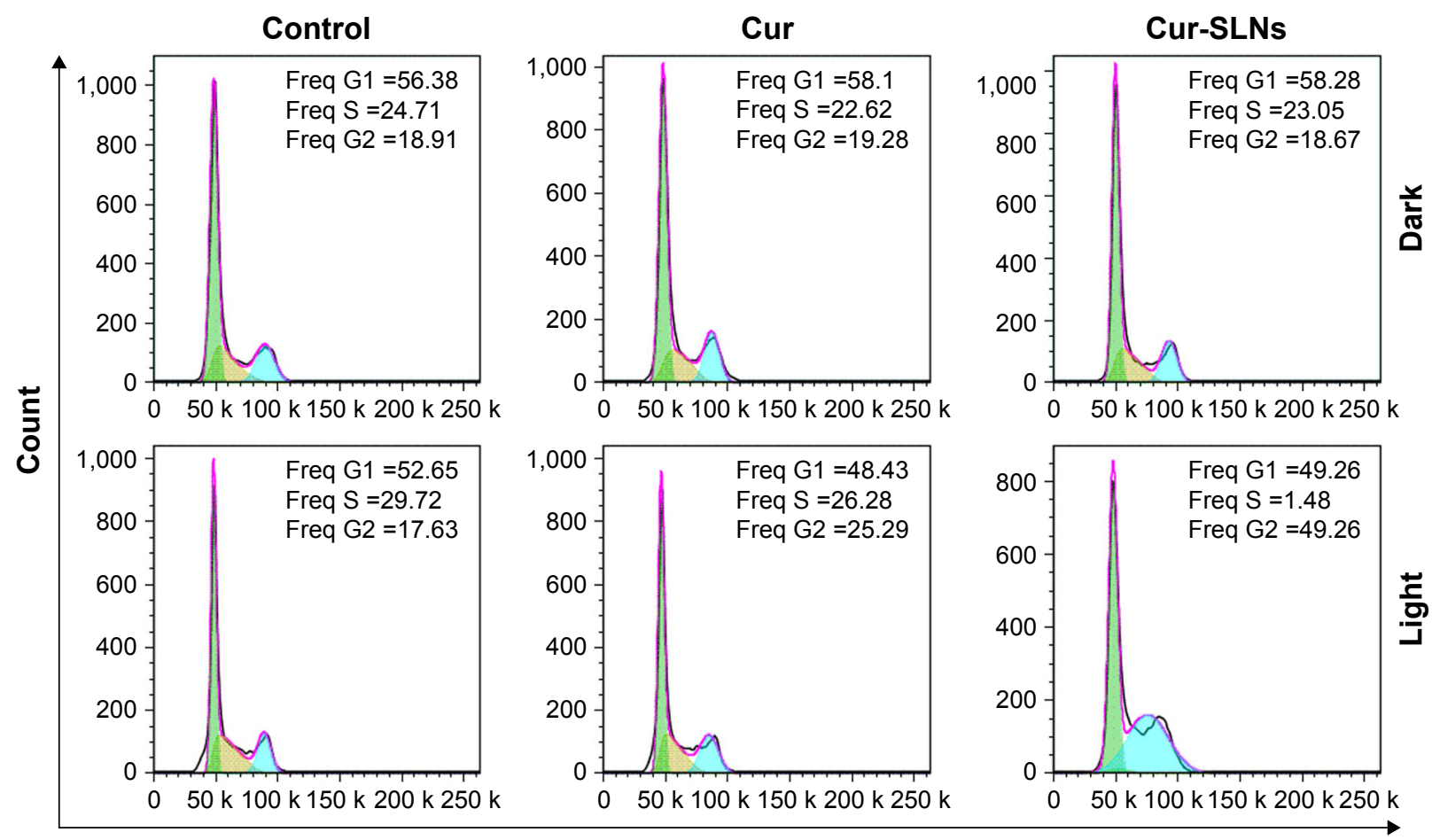

PI

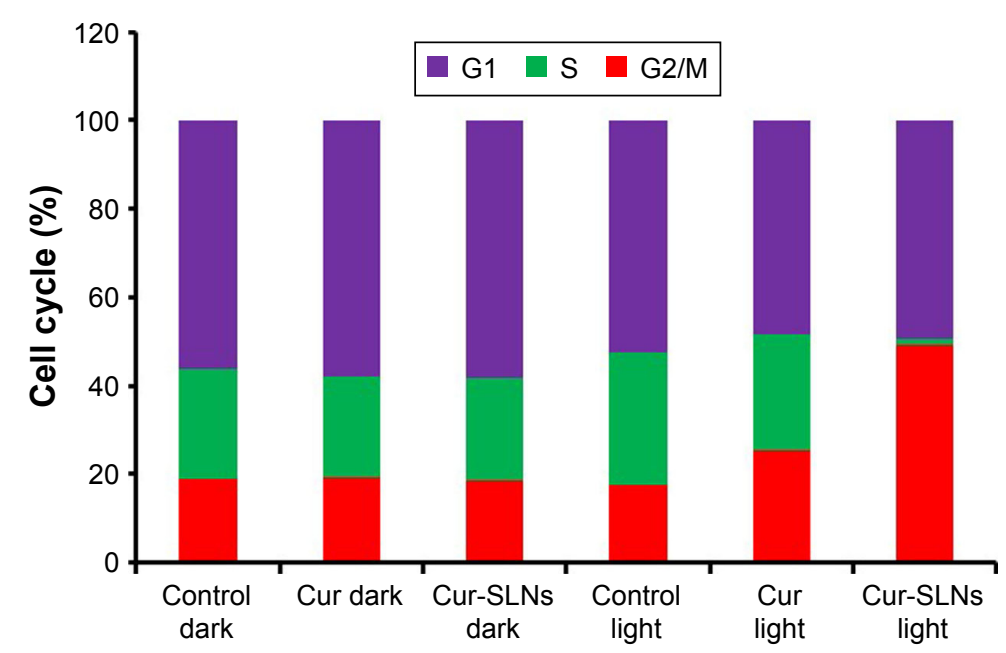

Figure 4 Cell cycle analysis of A549 cells treated with Cur and Cur-SLNs in the dark or with irradiation, and bar diagrammatic representation showing the percentage cell distribution in different phases of cell cycle.

Abbreviations: Cur, curcumin; Cur-SLNs, curcumin-loaded solid lipid nanoparticles; Freq, Frequency; PI, propidium iodide.

In order to explore the mechanism by which Cur-SLNs induced higher PDT activity in comparison with free Cur, confocal microscopy was used, which showed that the fluorescence intensity of Cur-SLNs could be observed within $1 \mathrm{~h}$ and became stronger after $4 \mathrm{~h}$ of incubation in A549 cells, while free Cur showed only weak green fluorescence. It could be deduced that Cur-SLNs were more stable and soluble than free Cur. Coincubation of A549 cells with Cur-SLNs and Mito-Tracker Deep Red showed that the drug was enriched in mitochondria.
The mitochondrion is an essential organelle supplying energy and regulating apoptosis in cells, usually be used as a target in PDT. ${ }^{40}$

It is well known that Cur exposed to $430 \mathrm{~nm}$ light could generate a large amount of ROS, inducing the apoptosis of cancer cells. ${ }^{32,37,41}$ Cytotoxic intracellular ROS can cause damage to mitochondria in cells, resulting in cell death. Our results demonstrated that SLN was a good drug delivery system for Cur, which enhanced its intracellular uptake and slowed down its hydrolysis in PDT. 


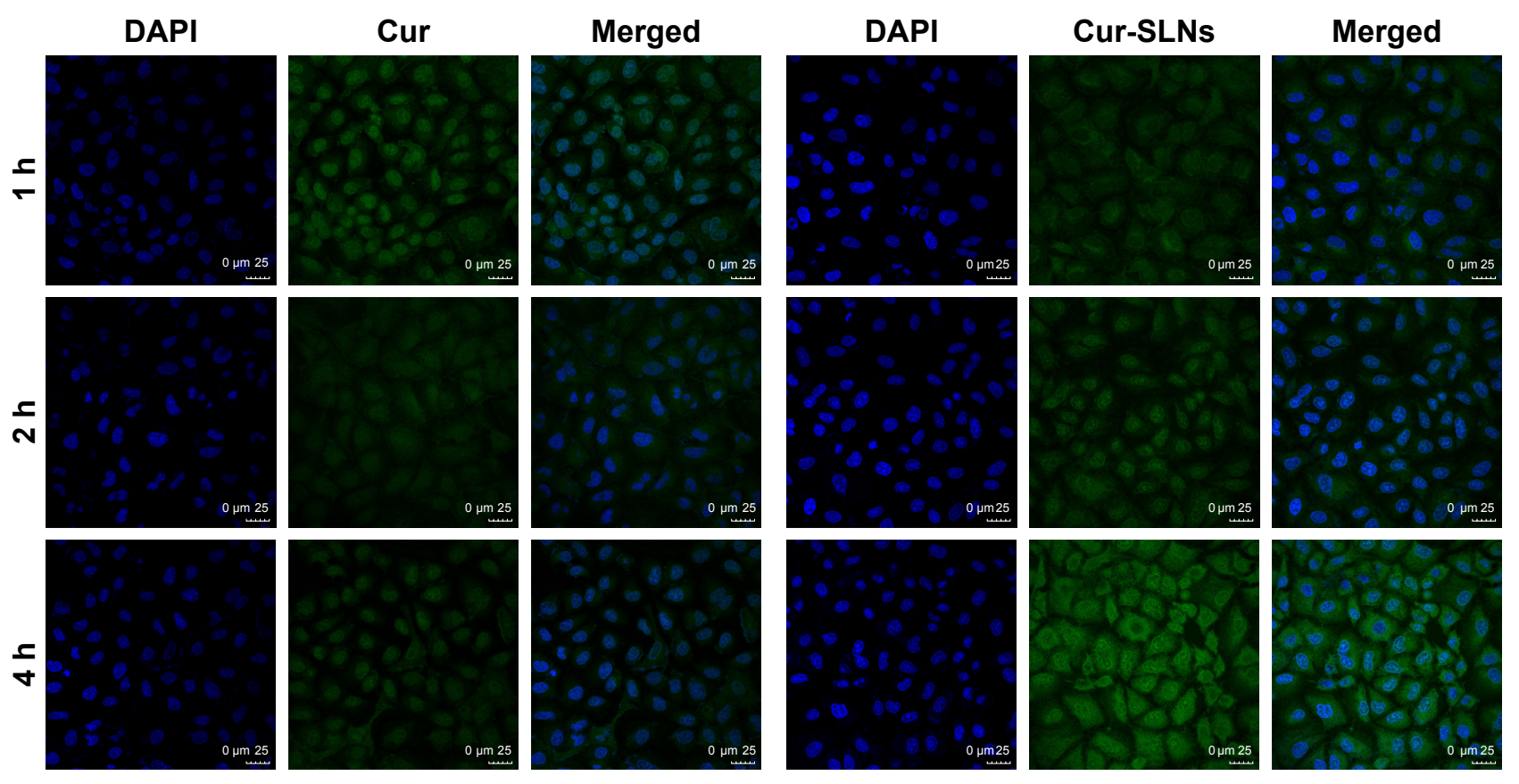

Figure 5 Intracellular uptake study of free Cur and Cur-SLNs in A549 cells.

Abbreviations: Cur, curcumin; Cur-SLNs, curcumin-loaded solid lipid nanoparticles; DAPI, 2-(4-amidinophenyl)-6-indolecarbamidine dihydrochloride.

Previous reports show that loss of mitochondrial membrane potential $(\Delta \Psi \mathrm{m})$ is an early event in apoptosis. This is because the ROS burst activates an inner membrane anion channel and promotes the opening of mitochondrial permeability transition pore by oxidation of matrix glutathione. ${ }^{42}$ High levels of ROS can disrupt the mitochondrial permeability transition pore and destroy the integrity of the mitochondrial membrane, resulting in immediate dissipation of mitochondrial transmembrane potential and osmotic swelling of the mitochondrial matrix..$^{43,44}$ Once
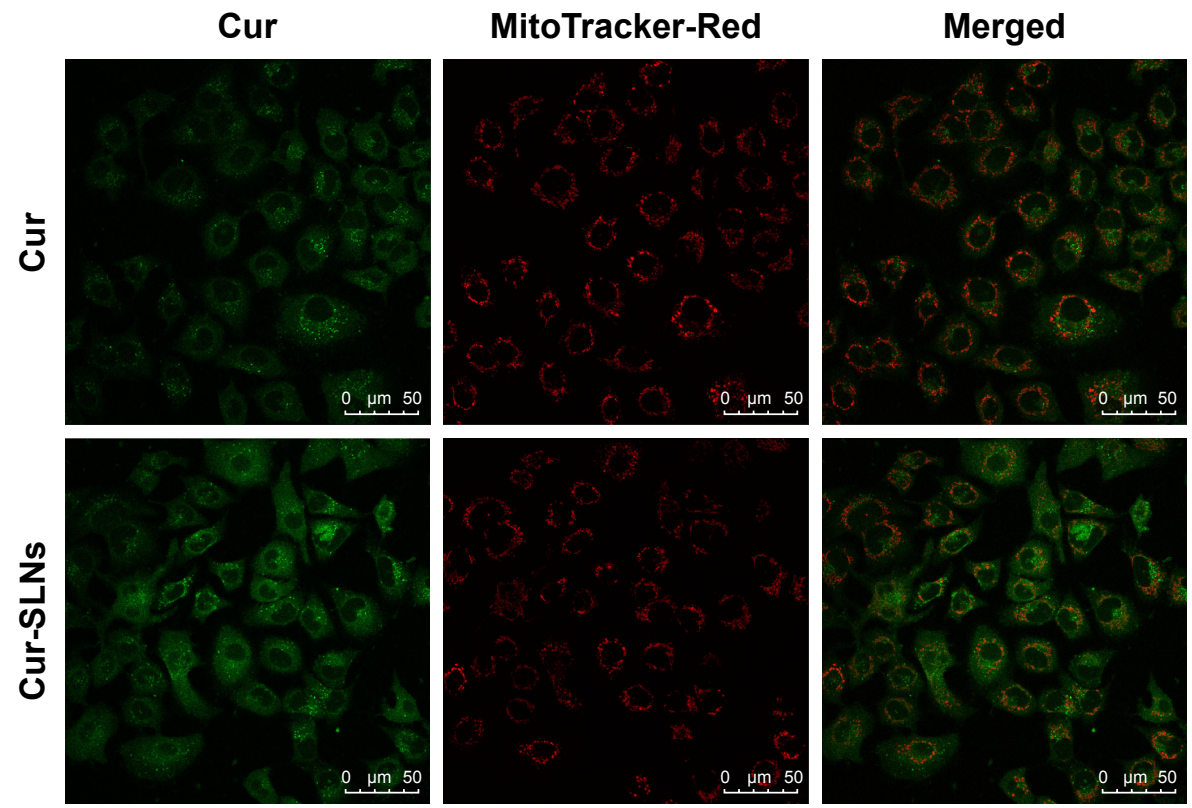

Figure 6 Cellular uptake of Cur and Cur-SLNs at $4 \mathrm{~h}$.

Note: Confocal imaging of the colocalization of Cur and Cur-SLNs with mitochondria (MitoTracker-Red).

Abbreviations: Cur, curcumin; Cur-SLNs, curcumin-loaded solid lipid nanoparticles. 

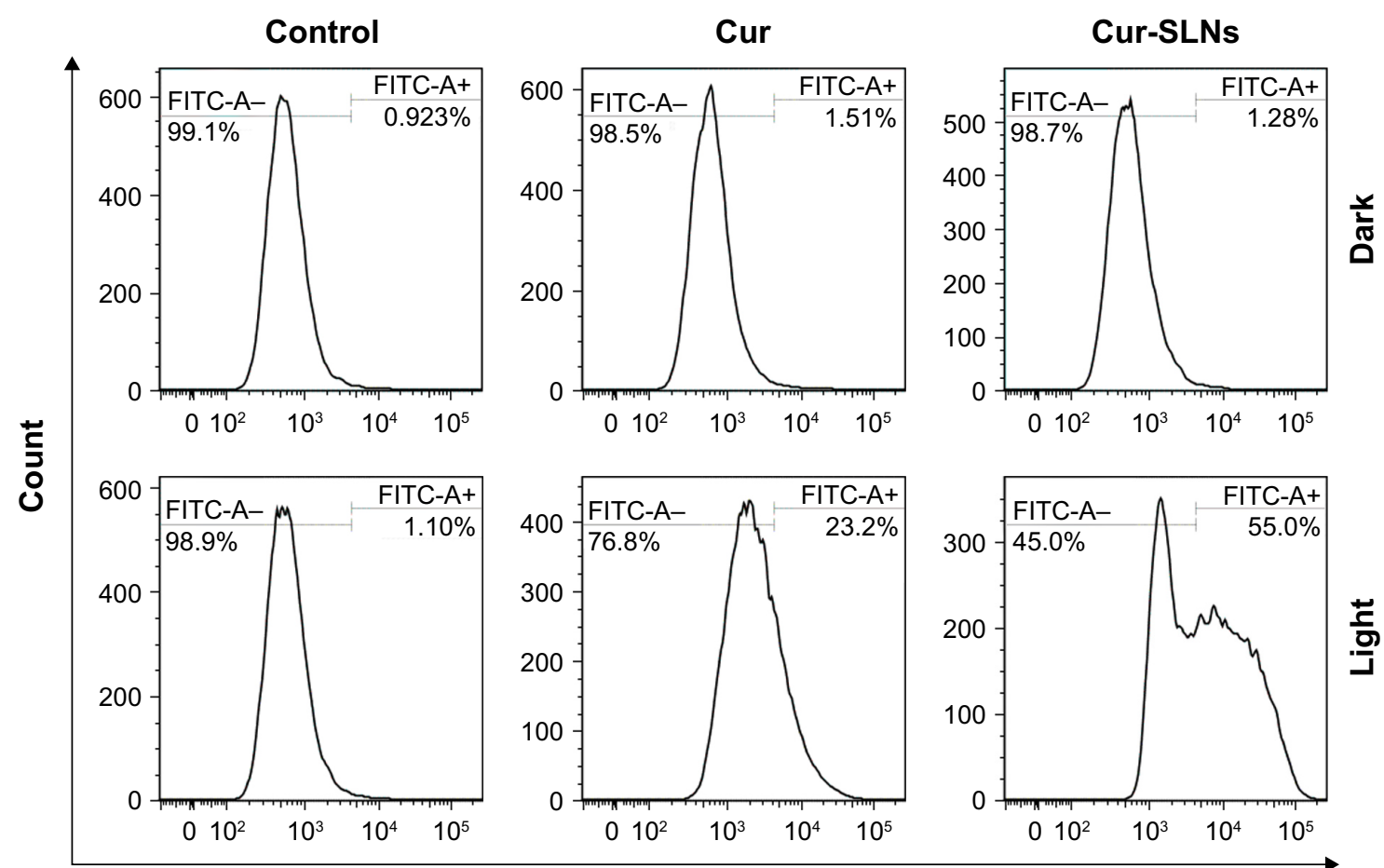

Fluorescence intensity of DCF

Figure 7 DCFH-DA/DCFH assay performed for the detection of ROS generation by Cur and Cur-SLNs in A549 cells.

Abbreviations: Cur, curcumin; Cur-SLNs, curcumin-loaded solid lipid nanoparticles; DCFH, dichlorodihydrofluorescein diacetate; DCFH-DA, 2',7'-dichlorofluorescin diacetate; FITC, fluorescein isothiocyanate; ROS, reactive oxygen species.
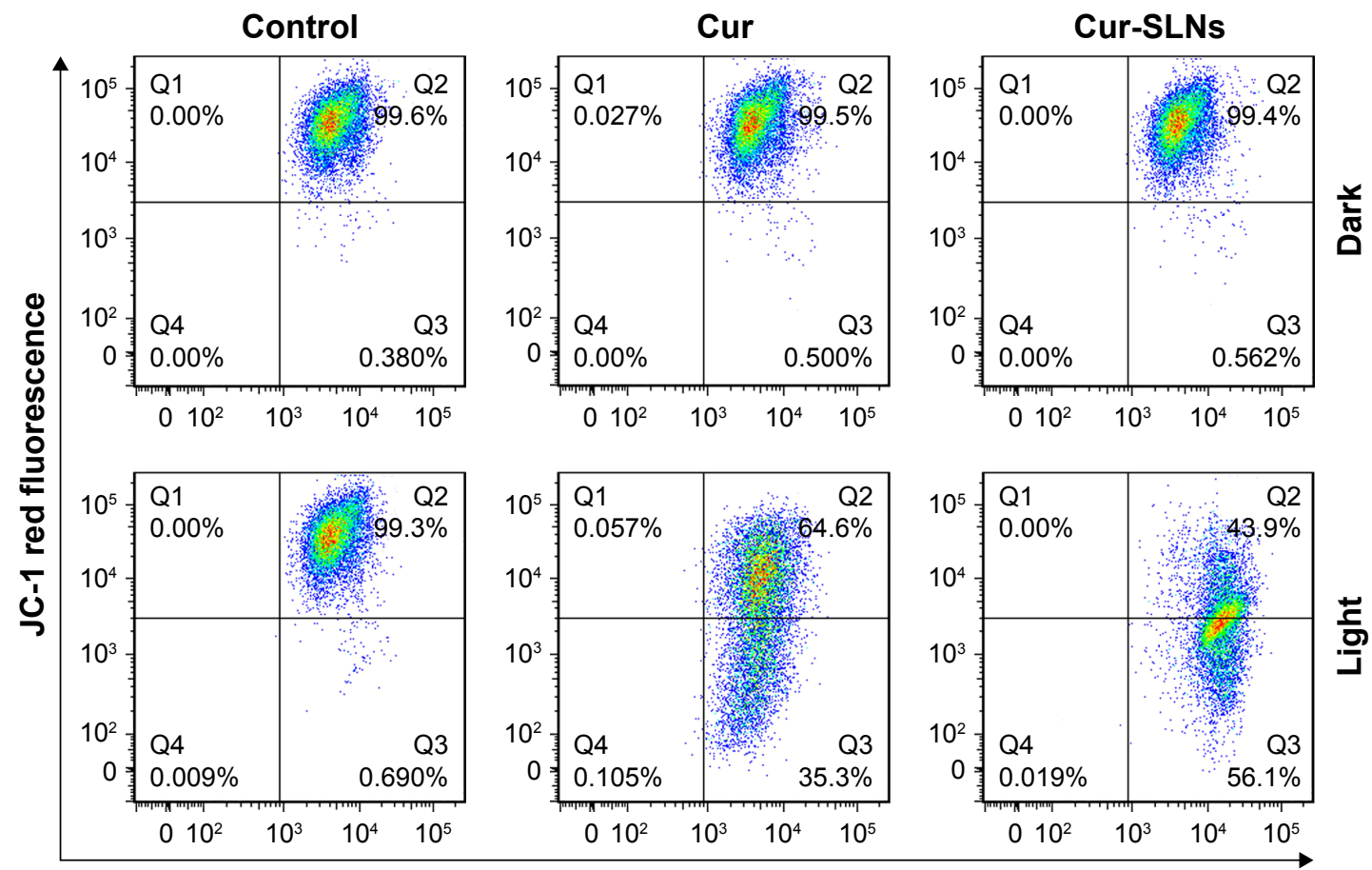

JC-1 green fluorescence

Figure 8 FACS analysis of JC-I stained cells for the detection of mitochondrial membrane potential changes induced by Cur and Cur-SLNs in A549 cells.

Abbreviations: Cur, curcumin; Cur-SLNs, curcumin-loaded solid lipid nanoparticles; FACS, fluorescence-activated cell sorter; JC-I, 3 '-tetraethylbenzimidazolcarbocyanine iodide. 

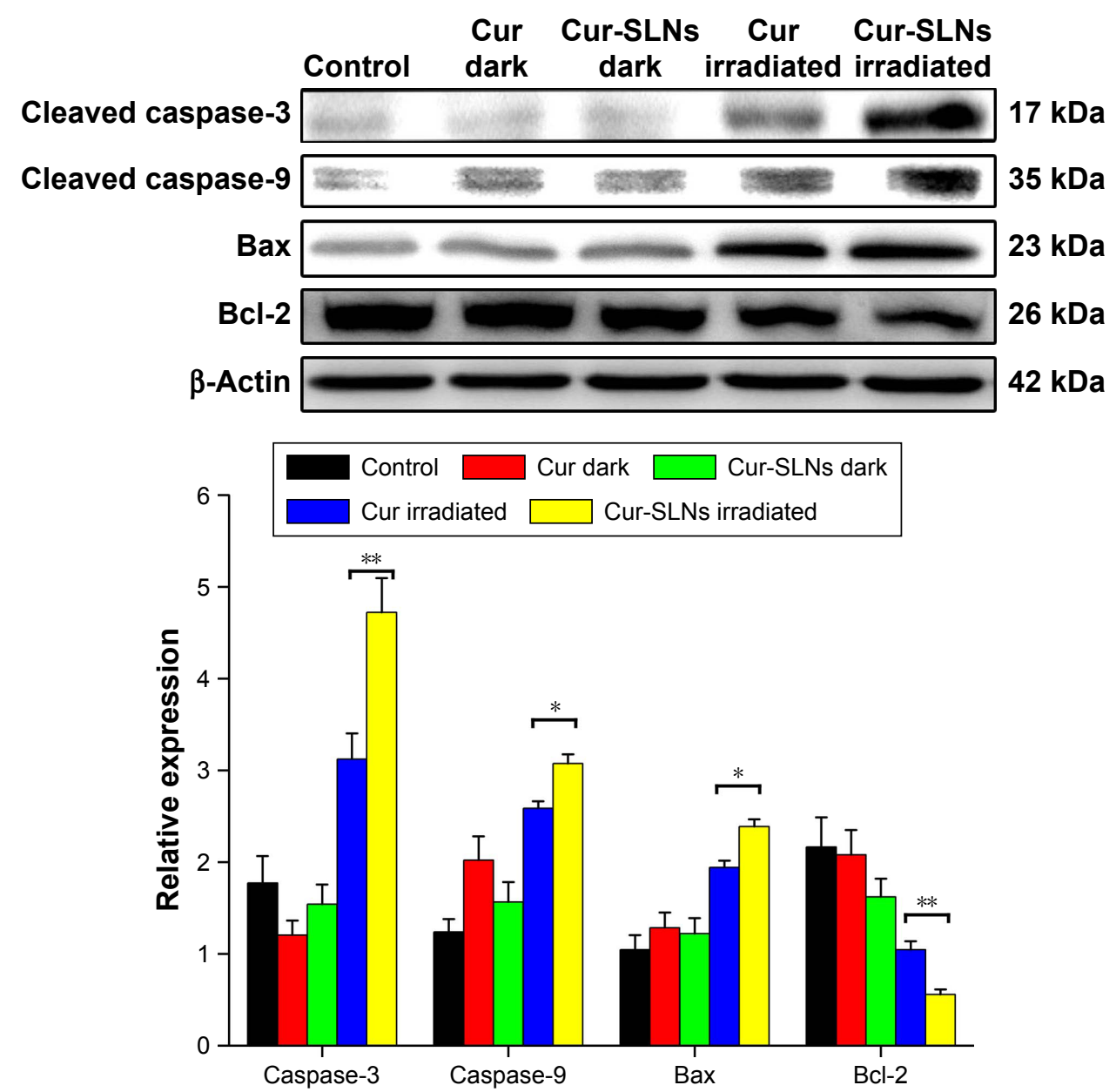

Figure 9 Expression of caspase-3, caspase-9, Bax, and Bcl-2 proteins by Western blotting analysis after 20 min of irradiation using a $430 \mathrm{~nm}$ LED.

Notes: The statistical significances in Cur and Cur-SLNs groups were determined using a two-sample Student's t-test. The data are shown as mean \pm standard deviation of three experiments; $* P<0.05, * * P<0.01$.

Abbreviations: Cur, curcumin; Cur-SLNs, curcumin-loaded solid lipid nanoparticles; LED, light-emitting diode.

there is no exchange of small molecules between the matrix and the cytoplasm, mitochondrial energy production stops and cell apoptosis occurs. In our study, the mitochondrial membrane potential of Cur-SLN-treated group showed more serious collapse compared to that of free Cur group.

In order to investigate the underlying molecular mechanism, the proapoptotic protein Bax and the antiapoptotic protein Bcl-2 were measured by Western blotting. The antiapoptotic protein $\mathrm{Bcl}-2$ can counteract the proapoptotic activity from Bax, and the ratio of Bax/Bcl-2 might be another useful factor in the cellular threshold for undergoing apoptosis induced by PDT ${ }^{45}$ Many studies have shown that activation of the caspase protein family triggers the apoptotic process in cells. Caspase- 9 cleaved and activated procaspase-3. ${ }^{36,46-49}$ Activation of caspase-3 resulted in the apoptosis of cell, including cell shrinkage, membrane blebbing, and internucleosomal DNA fragmentation. Figure 10 shows that after PDT treatment, the expression levels of caspase-3 and caspase- 9 improved significantly and the expression in Cur-SLN-treated group was higher compared to that in Cur-treated group. The ratio of $\mathrm{Bax} / \mathrm{Bcl}-2$ was lower in Cur-SLN-treated group compared to that in Cur-treated group. This indicates that induction of apoptosis after PDT treatment may be through a caspase-dependent mechanism and that Cur delivered by SLNs can induce more apoptosis of A549 cells. In conclusion, Cur-SLNs may be used as a promising therapeutic agent for cancer treatment.

\section{Conclusion}

In this study, we found that SLNs could be used as a potential drug delivery carrier which largely enhances the cancer cell killing efficiency of Cur exposed to $430 \mathrm{~nm}$ light. This surprising effect was because the SLN-based delivery system dramatically increased intracellular shuttling of Cur, enhanced the hydrolytic stability of Cur, and increased light-induced ROS formation. Altogether, our data showed the promise of using SLNs in combined phototherapies with synergistic efficacies for treating cancer. 


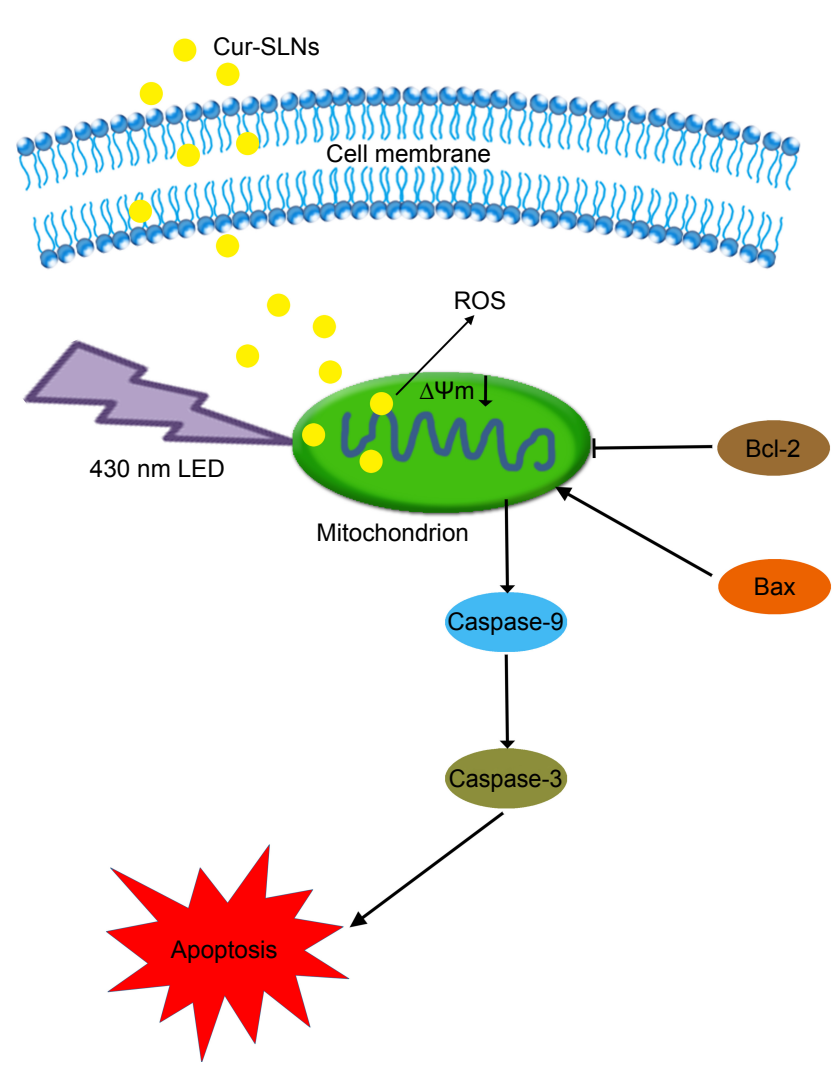

Figure 10 The signaling pathways and mechanism of Cur-SLNs in A549 cells. Abbreviations: Cur-SLNs, curcumin-loaded solid lipid nanoparticles; LED, lightemitting diode; ROS, reactive oxygen species.

\section{Acknowledgments}

This work was financially supported by the National Natural Science Foundation of China (Grant Nos 31570849, 81671105), the National key research and development program (Grant No 2016YFA0100800), and the Fundamental Research Funds for the Central Universities.

\section{Disclosure}

The authors report no conflicts of interest in this work.

\section{References}

1. Agostinis P, Berg K, Cengel KA, et al. Photodynamic therapy of cancer: an update. CA Cancer J Clin. 2011;61(4):250-281.

2. Dou QQ, Teng CP, Ye E, Loh XJ. Effective near-infrared photodynamic therapy assisted by upconversion nanoparticles conjugated with photosensitizers. Int J Nanomedicine. 2015;10:419-432.

3. Yu Z, Sun Q, Pan W, Li N, Tang B. A near-infrared triggered nanophotosensitizer inducing domino effect on mitochondrial reactive oxygen species burst for cancer therapy. ACS Nano. 2015;9(11): 11064-11074.

4. Khaing Oo MK, Yang YM, Hu Y, Gomez M, Du H, Wang HJ. Gold nanoparticle-enhanced and size-dependent generation of reactive oxygen species from protoporphyrin IX. ACS Nano. 2012;6(3):1939-1947.

5. Wang D, Fei B, Halig LV, et al. Targeted iron-oxide nanoparticle for photodynamic therapy and imaging of head and neck cancer. ACS Nano. 2014;8(7):6620-6632.

6. Aggarwal BB, Shishodia S. Molecular targets of dietary agents for prevention and therapy of cancer. Biochem Pharmacol. 2006;71(10): $1397-1421$.
7. Goel A, Kunnumakkara AB, Aggarwal BB. Curcumin as "Curecumin": from kitchen to clinic. Biochem Pharmacol. 2008;75(4):787-809.

8. Wang J, Zhu RR, Sun DM, et al. Intracellular uptake of curcumin-loaded solid lipid nanoparticles exhibit anti-inflammatory activities superior to those of curcumin through the NF-kappa B signaling pathway. J Biomed Nanotechnol. 2015;11(3):403-415.

9. Araujo NC, Fontana CR, Bagnato VS, Gerbi ME. Photodynamic effects of curcumin against cariogenic pathogens. Photomed Laser Surg. 2012; 30(7):393-399.

10. Banerjee S, Prasad P, Hussain A, Khan I, Kondaiah P, Chakravarty AR. Remarkable photocytotoxicity of curcumin in HeLa cells in visible light and arresting its degradation on oxovanadium(IV) complex formation. Chem Commun (Camb). 2012;48(62):7702-7704.

11. Khorsandi K, Hosseinzadeh R, Fateh M. Curcumin intercalated layered double hydroxide nanohybrid as a potential drug delivery system for effective photodynamic therapy in human breast cancer cells. RSC Adv . 2015;5(114):93987-93994.

12. Koon H, Leung AW, Yue KK, Mak NK. Photodynamic effect of curcumin on NPC/CNE2 cell. J Environ Pathol Toxicol Oncol. 2006;25(1-2): 205-215.

13. Garai A, Pant I, Banerjee S, Banik B, Kondaiah P, Chakravarty AR. Photorelease and cellular delivery of mitocurcumin from its cytotoxic cobalt(III) complex in visible light. Inorg Chem. 2016;55(12): 6027-6035.

14. Sarkar T, Butcher RJ, Banerjee S, Mukherjee S, Hussain A. Visible lightinduced cytotoxicity of a dinuclear iron(III) complex of curcumin with low-micromolar IC50 value in cancer cells. Inorganica Chim Acta. 2016; 439:8-17.

15. Ye Y, Li Y, Fang F. Upconversion nanoparticles conjugated with curcumin as a photosensitizer to inhibit methicillin-resistant Staphylococcus aureus in lung under near infrared light. Int J Nanomedicine. 2014;9:5157-5165.

16. Sarkar T, Banerjee S, Mukherjee S, Hussain A. Mitochondrial selectivity and remarkable photocytotoxicity of a ferrocenyl neodymium(III) complex of terpyridine and curcumin in cancer cells. Dalton Trans. 2016;45(15):6424-6438.

17. Mitra K, Gautam S, Kondaiah P, Chakravarty AR. The cisdiammineplatinum(II) complex of curcumin: a dual action DNA crosslinking and photochemotherapeutic agent. Angew Chem Int Ed Engl. 2015;54(47):13989-13993.

18. Banerjee S, Pant I, Khan I, et al. Remarkable enhancement in photocytotoxicity and hydrolytic stability of curcumin on binding to an oxovanadium(IV) moiety. Dalton Trans. 2015;44(9):4108-4122.

19. Banerjee S, Chakravarty AR. Metal complexes of curcumin for cellular imaging, targeting, and photoinduced anticancer activity. Acc Chem Res. 2015;48(7):2075-2083.

20. Anand P, Kunnumakkara AB, Newman RA, Aggarwal BB. Bioavailability of curcumin: problems and promises. Mol Pharm. 2007;4(6): 807-818.

21. Pan MH, Huang TM, Lin JK. Biotransformation of curcumin through reduction and glucuronidation in mice. Drug Metab Dispos. 1999;27(4): 486-494.

22. Sharma RA, Steward WP, Gescher AJ. Pharmacokinetics and pharmacodynamics of curcumin. Adv Exp Med Biol. 2007;595:453-470.

23. Anand P, Nair HB, Sung B, et al. Design of curcumin-loaded PLGA nanoparticles formulation with enhanced cellular uptake, and increased bioactivity in vitro and superior bioavailability in vivo. Biochem Pharmacol. 2010;79(79):330-338.

24. Yadav VR, Prasad S, Kannappan R, et al. Cyclodextrin-complexed curcumin exhibits anti-inflammatory and antiproliferative activities superior to those of curcumin through higher cellular uptake. Biochem Pharmacol. 2010;80(7):1021-1032.

25. Anitha A, Maya S, Deepa N, et al. Efficient water soluble Ocarboxymethyl chitosan nanocarrier for the delivery of curcumin to cancer cells. Carbohydr Polym. 2011;83(2):452-461.

26. Yallapu MM, Ebeling MC, Chauhan N, Jaggi M, Chauhan SC. Interaction of curcumin nanoformulations with human plasma proteins and erythrocytes. Int J Nanomedicine. 2011;6(1):2779-2790. 
27. Perez AP, Casasco A, Schilrreff P, et al. Enhanced photodynamic leishmanicidal activity of hydrophobic zinc phthalocyanine within archaeolipids containing liposomes. Int J Nanomedicine. 2014;9(1): 3335-3345.

28. Wang J, Zhu R, Sun X, Zhu Y, Liu H, Wang SL. Intracellular uptake of etoposide-loaded solid lipid nanoparticles induces an enhancing inhibitory effect on gastric cancer through mitochondria-mediated apoptosis pathway. Int J Nanomedicine. 2014;9(4):3987-3998.

29. Wang W, Zhu R, Xie Q, et al. Enhanced bioavailability and efficiency of curcumin for the treatment of asthma by its formulation in solid lipid nanoparticles. Int J Nanomedicine. 2011;7(7):3667-3677.

30. Farboud ES, Nasrollahi SA, Tabbakhi Z. Novel formulation and evaluation of a Q10-loaded solid lipid nanoparticle cream: in vitro and in vivo studies. Int J Nanomedicine. 2011;6:611-617.

31. Xie S, Pan B, Shi B, et al. Solid lipid nanoparticle suspension enhanced the therapeutic efficacy of praziquantel against tapeworm. Int J Nanomedicine. 2011;6(1):2367-2374.

32. Yuan Y, Min Y, Hu Q, Xing B, Liu B. NIR photoregulated chemo- and photodynamic cancer therapy based on conjugated polyelectrolytedrug conjugate encapsulated upconversion nanoparticles. Nanoscale. 2014;6(19):11259-11272.

33. Cui S, Yin D, Chen Y, et al. In vivo targeted deep-tissue photodynamic therapy based on near-infrared light triggered upconversion nanoconstruct. ACS Nano. 2012;7(1):676-688.

34. Tian B, Wang C, Zhang S, Feng L, Liu Z. Photothermally enhanced photodynamic therapy delivered by nano-graphene oxide. ACS Nano. 2011;5(9):7000-7009.

35. Sahoo SK, Panyam J, Prabha S, Labhasetwar V. Residual polyvinyl alcohol associated with poly (D,L-lactide-co-glycolide) nanoparticles affects their physical properties and cellular uptake. J Control Release. 2002;82(1):105-114.

36. Wang H, Wang X, Zhang S, Wang P, Zhang K, Liu Q. Sinoporphyrin sodium, a novel sensitizer, triggers mitochondrial-dependent apoptosis in ECA-109 cells via production of reactive oxygen species. Int J Nanomedicine. 2014;9(1):3077-3090.

37. Sarkar T, Banerjee S, Hussain A. Remarkable visible light-triggered cytotoxicity of mitochondria targeting mixed-ligand cobalt(III) complexes of curcumin and phenanthroline bases binding to human serum albumin. RSC Adv. 2015;5(22):16641-16653.

38. Mohanty C, Acharya S, Mohanty AK, Dilnawaz F, Sahoo SK. Curcuminencapsulated MePEG/PCL diblock copolymeric micelles: a novel controlled delivery vehicle for cancer therapy. Nanomedicine (Lond). 2010; $5(3): 433-449$.
39. Saxena V, Hussain MD. Polymeric mixed micelles for delivery of curcumin to multidrug resistant ovarian cancer. J Biomed Nanotechnol. 2013; 9(7):1146-1154.

40. Hackbarth S, Schlothauer J, Preuß A, Röder B. New insights to primary photodynamic effects - singlet oxygen kinetics in living cells. J Photochem Photobiol B. 2010;98(3):173-179.

41. Liao ZX, Li YC, Lu HM, Sung HW. A genetically-encoded KillerRed protein as an intrinsically generated photosensitizer for photodynamic therapy. Biomaterials. 2014;35(1):500-508.

42. Wang G, Liu C, Liu J, et al. Exopolysaccharide from Trichoderma pseudokoningii induces the apoptosis of MCF-7 cells through an intrinsic mitochondrial pathway. Carbohydr Polym. 2016;136:1065-1073.

43. Zhou T, Dang Y, Zheng YH. The mitochondrial translocator protein, TSPO, inhibits HIV-1 envelope glycoprotein biosynthesis via the endoplasmic reticulum-associated protein degradation pathway. J Virol. 2014;88(6):3474-3484.

44. Zhang S, Yang L, Ling X, et al. Tumor mitochondria-targeted photodynamic therapy with a translocator protein (TSPO)-specific photosensitizer. Acta Biomater. 2015;28:160-170.

45. Hou Z, Zhang Y, Deng K, et al. UV-emitting upconversion-based TiO2 photosensitizing nanoplatform: near-infrared light mediated in vivo photodynamic therapy via mitochondria-involved apoptosis pathway. ACS Nano. 2015;9(3):2584-2599.

46. Wang F, Yang X, Ma L, et al. Multifunctional up-converting nanocomposites with multimodal imaging and photosensitization at near-infrared excitation. J Mater Chem. 2012;22(47):24597-24604.

47. Sivanantham B, Sethuraman S, Krishnan UM. Combinatorial effects of curcumin with an anti-neoplastic agent on head and neck squamous cell carcinoma (HNSCC) through the regulation of EGFR-ERK1/2 and apoptotic signaling pathways. ACS Comb Sci. 2016;18(1):22-35.

48. Biswas R, Chung PS, Moon JH, Lee SH, Ahn JC. Carboplatin synergistically triggers the efficacy of photodynamic therapy via caspase 3-, 8-, and 12-dependent pathways in human anaplastic thyroid cancer cells. Lasers Med Sci. 2014;29(3):995-1007.

49. Zhu R, Wang Q, Zhu Y, et al. pH sensitive nano layered double hydroxides reduce the hematotoxicity and enhance the anticancer efficacy of etoposide on non-small cell lung cancer. Acta Biomater. 2015; $29: 320-332$.
International Journal of Nanomedicine

\section{Publish your work in this journal}

The International Journal of Nanomedicine is an international, peerreviewed journal focusing on the application of nanotechnology in diagnostics, therapeutics, and drug delivery systems throughout the biomedical field. This journal is indexed on PubMed Central, MedLine, CAS, SciSearch ${ }^{\circledR}$, Current Contents ${ }^{\circledR} /$ Clinical Medicine,

\section{Dovepress}

Journal Citation Reports/Science Edition, EMBase, Scopus and the Elsevier Bibliographic databases. The manuscript management system is completely online and includes a very quick and fair peer-review system, which is all easy to use. Visit http://www.dovepress.com/ testimonials.php to read real quotes from published authors. 